\title{
Intercultural Competence in Intercultural Business Communication
}

\author{
Min Zheng \\ Business College, Linyi University, Linyi, China \\ Email: lisazhengus@hotmail.com
}

Received 22 February 2015; accepted 22 March 2015; published 23 March 2015

Copyright (C) 2015 by author and Scientific Research Publishing Inc.

This work is licensed under the Creative Commons Attribution International License (CC BY). http://creativecommons.org/licenses/by/4.0/

(c) (i) Open Access

\begin{abstract}
With the development of the integration of the world and the language and culture, the cultivation of intercultural communicative competence has become the ultimate goal of the foreign language teaching. This paper begins by analyzing personal understandings of successful Intercultural Business Communication skills and importance of learning Intercultural Business Communication skills, followed by four stages in experiencing a new culture skills, and at last it brings forward four action plans to improve the skills.
\end{abstract}

Keywords

Intercultural Competence, Assessment of ICBC, Categories, Active Listening

\section{Introduction}

Everyone is shaped by their own culture whether they know it or not. Our very thoughts and actions are dependent on our culture. These thoughts and actions are so integrated that we don't even think about them until we are confronted with another culture and another way of doing things. This paper begins by analyzing personal understandings of successful Intercultural Business Communication skills and importance of learning Intercultural Business Communication skills, followed by assessment of individual ICBC (abbreviation of Intercultural Business Communication) skills, and at last it brings forward four action plans to improve the skills.

\section{Understanding of 4 Steps to Good ICBC Skills}

\subsection{Taking Positive Attitudes in Effective ICBC}

The first step in effective intercultural communication involves self-analysis, self-awareness and understanding [1]. You can't understand the other party unless you understand yourself. The next step is the understanding and 
acceptance of difference. That does not mean we have to agree with another culture's viewpoint or adopt another culture's values. It does mean we and they must examine our and their priorities and determine how we can do best work together, being different.

\subsection{Adaptability in Effective ICBC}

In the process, we will realize that a person entering another culture will always have to adapt to a number of cultural conditions. That doesn't mean turning one's back on one's own culture or denying its priorities. Rather, it means learning what motivates others and how other cultural priorities inform the behavior, attitudes and values of business colleagues. This approach means adding to one's own culture, not subtracting from it. For example, a businessman from New Zealand going to Japan must adapt to many Japanese practices, just as a Japanese businessman going to New Zealand must adopt to a variety of New Zealand practices. This brings the third step in improving ICBC skills - to challenge the categories we have used and see them as flexible and incomplete. In any intercultural encounter, variations will occur. What we expect won't be exactly what we get. Openness and willingness to learn characterize the skilled person in intercultural communication.

\subsection{Using Categories to Understand How Culture Differs}

The third step in developing intercultural communication skills is to use categories-that is, tools for understanding how cultures compare [2]. In attempting to understand another culture's perspective, we will gain greater ground if we take off our cultural blinders and develop sensitivity in the way we speak and behave. That is not always easy. We are culturally based and culturally biased.

\subsection{Enacting What One Has Learned}

The last step in intercultural communication competence is enacting what one has learned. You know as a newcomer to a culture when you have done something that is culturally correct; you can act in accord with the other culture without being aware of making an effort. Positive results come with ease. At that point, you are walking in the shoes of the other culture. That is the ultimate goal of learning about a culture and learning the skills to communicate with that culture: to behave as if you are of that culture.

\section{Importance of Learning Intercultural Business Communication Skills}

Intercultural communication occurs when people of diverse ethnic backgrounds discuss ideas and tasks in a language other than their native tongue. With the explosion of global business, productive intercultural communication has become more important. Successful intercultural communication is effective, frequent, and simple while also respecting the cultural viewpoints of all participants. The ability to communicate effectively across cultures gives both businesspersons and their organizations tangible benefits, such as: quick problem solving, stronger decision-making, increased productivity, steadier work flow, strong business relationships, enhanced professional image and so on.

Learning intercultural business communication skills is especially important to us who are majoring in international business or foreign language studies, where there is an urgent need for highly developed interpersonal communication skills and competence. It is also important to be knowledgeable about the organization that a particular person works for, and how its structure and its organizational culture affect its communications.

\section{Four Stages in Experiencing a New Culture}

There are approximately four stages in experiencing a new culture: euphoria, frustration, adjustment and integration [3]. Taking my studying experience in United States as example, in the first stage, everything in the new culture attracted me to explore more, I like communicating with different people from different cultures, but most of communication is defined to simple issues like weather, home country, course information and something like that. In the second stage, I like to use the phrase "culture shock" to express my feelings. I find out that there are inadequacies in my understanding of culture there. Inevitably there are disappointments in myself and in others; inevitably I make mistakes. I find myself homesick and become reluctant to communicate with foreigners. Because I had a thought that native members seem to have superior status and take advantage of us. In 
the third stage, when I see both sides and learn more about how the culture works, I am able to cooperate more effectively with members of the natives. In the last stage, I became fluent enough in the American culture to move easily within it and feel at ease.

\section{Action Plan to Improve ICBC Skills}

\subsection{Keep It Simple}

Successful intercultural communication avoids translation errors by using simple language and repeating important points in different ways [4]. Avoid long, complex sentences and jargon for optimal communication. In written communications, bullet point lists are helpful in identifying key information without the distraction of a long sentence. Verbal presentations should be given at a slower pace with special attention to enunciation as well as stopping to verify everyone understands what was said. Visual aids should be used whenever possible to highlight key points in writing.

\subsection{Cultural Knowledge}

Understanding cultural history and etiquette are keystones of successful intercultural communication. Knowing how to properly present a business card and who receives one first can set the stage for a productive business interaction. Successful intercultural communication requires basic understanding of cultural mores and adapting business communication style to them as much as possible. Study the culture of business associates and know what is considered rude to avoid mistakes.

\subsection{Engage in Active Listening}

In order to improve communication skills across cultures, we should engage in listening to their workers. The focus should be on listening to understand, not to judge. We should actively assist in working problems by sharing themselves with others and demonstrating respect and concern. Active listening breeds cross-cultural interpersonal sensitivity defined as: the ability to hear what people from a foreign culture are really saying or meaning, and an ability to predict how they will react [5].

\subsection{Open up to New Ideas, Be Optimistic and Appreciate Cultural Differences}

Opening up to new ideas, being optimistic and appreciating cultural differences is another way to improve communication skills. This requires that we should listen more, talk less and be honest with themselves and with their team. Specifically, we can improve by spending time with team members. They should attend social functions after work hours and get involved in sponsoring cultural awareness activities. These functions will enhance cultural understanding of diverse cultural teams, while going a long way to engender respect for one another's points of view.

\section{Conclusion}

This paper has outlined an integrative model of intercultural competence. Intercultural competence is defined via the interplay of social, individual, professional and strategic sub-competencies which correspond to the areas cognition, behavior and affect. Further, I conceptualize intercultural competence on the basis of the notion of culture as consisting of multiple collectives. That is, there is no cultural standard valid for everyone in a perceived culture as cultures contain a broad range of diversity. Individuals partake in various collectives yet perceive themselves as members of a certain culture.

\section{References}

[1] Ostendorf, A.M. (2012) Intercultural business communication. Business Communication Quarterly: BCQ, 75, $221-224$. http://dx.doi.org/10.1177/1080569911432552

[2] Yang, J. (2013) An Empirical Study on Improving Intercultural Communicative Competence of College Students. Journal of Chongqing University (Social Science Edition), 19, 174-179.

[3] Fu, Z.Y. (2010) A Study of How to Develop Students’ Intercultural Communication Competence (ICC) in Business English Teaching (BET). Asian Social Science, 4, 84. 
[4] Peng, R.Z. and Fan, W.W. (2011) Analyzing the Key Factors Affecting China’s College Students' Intercultural Competence. 2011 4th IEEE International Conference on Computer Science and Information Technology, 1, 457-461.

[5] Ainsworth, J. (2013) Business Languages for Intercultural and International Business Communication: A Canadian Case Study. Business Communication Quarterly: BCQ, 76, 28-50. http://dx.doi.org/10.1177/1080569912471186 